Saeculum Christianum vol. XXII (2015)

pp. $256-274$

\author{
MANLIO SODI *
}

Università Lateranense, Roma

GIACOMO BAROFFIO

Università di Pavia, Pavia

\title{
ALESSANDRO TONIOLO
}

\section{THE CONCORDANTIA OF THE THREE GREAT SACRAMENTARIES: GREGORIAN, VERONESE AND GELASIAN}

At the turn of the 3rd century, the history of the Missale Romanum was characterised by, apart from numerous studies thereupon, the composition of a work indispensable for understanding it more profoundly: the Concordantia.

1962 saw the publishing of the last editio typica of the Missale Romanum, derived from the liturgical form desired by the Council of Trent ${ }^{1}$; the year after, an edition of the Concordantia, edited by A. Pflieger, was published ${ }^{2}$. In 1975, the editio typica altera (secunda) of the Missale Romanum - published as the editio typica in 1970 - derived from the liturgical form desired by the Second Vatican Council ${ }^{3}$ was published. On the basis of that text, a Concordantia edited by T.A. Schnitker and W.A. Slaby ${ }^{4}$ was elaborated.

\footnotetext{
* Translated by Skrivanek Sp. z o.o.

1 Missale Romanum ex decreto Ss. Concilii Tridentini restitutum, Summorum Pontificum cura recognitum, Editio typica, Typis Polyglottis Vaticanis [ - 1962], pp. LXXXIII + $727+$ [282]. An undated anastatic reprint appeared in 2011, substituting the disputed oration of the Good Friday prayer for the Jews, but confirming its original title: no 8 . Pro conversione Iudceorum (p. 173). - For the history and evolution of this Missale, see M. Sodi - A.M. Triacca (ed.), Missale Romanum. Editio princeps (1570). Anastatic edition, Introduction and Appendix = Monumenta Liturgica Concilii Tridentini 2, Libreria Editrice Vaticana, Vatican City, 1998, 22012, pp. XLVI + 720; M. Sodi - A. Toniolo, Missale Romanum. Editio typica 1962. Anastatic edition and Introduction = Monumenta Liturgica Piana 1, Libreria Editrice Vaticana, Vatican City, 2007, pp. XVIII + 1096. The fifth volume of the selfsame series contains, among others, the Concordantia elaborated using the same criteria as the current one: cf. M. Sodi - A. Toniolo P. Bruylants (edd.), Liturgia tridentina. Fontes - Indices - Concordantia 1568-1962, cf M. Sodi - A. Toniolo P. Bruylants (edd.), Libreria Editrice Vaticana, Vatican City, 2010, pp. XIX + 1254. - Lastly, one must bear in mind the monographic file published in Rivista Liturgica 95/1 (2008), titled: Celebrare con il Messale di san Pio V. [T/N: Celebration with the Missal of St. Pius V]

2 Cf A. Pflieger, Liturgica orationis concordantia verbalia. Prima Pars: Missale Romanum, Herder, Romae MCMLIV, pp. XI + 740 .

3 See respectively: Missale Romanum ex decreto Sacrosancti Ecumenici Concilii Vaticani II instauratum, auctoritate Pauli PP. VI promulgatum, Editio typica, Typis Polyglottis Vaticanis MCMLXX, pp. 966; Editio typica altera MCMLXXV, pp. 999.

4 Cf T.A. Schnitker - W.A. Slaby (ed.), Concordantia verbalia Missalis Romani. Partes euchologicae, Aschendorff, Münster 1983, pp. XV + 1508 (3048 columns in total). See the elaborate "bibliographical note" of M. Sodi, Una concordanza verbale del "Missale Romanum" di Paolo VI, in Rivista Liturgica 71/3 (1984) 424-436.
} 
These two "tools of work" have come to be truly precious when it comes to facilitating the understanding of the values enshrined in the Missale, and remain indispensable for whoever wishes to familiarise themselves with those editions even today. On the other hand, they also allow the course of the history, evolution and conveyance of the formulae of the liber princeps of the Roman Rite Liturgy to be confirmed.

The publishing of the editio typica tertia of the Missale ${ }^{5}$ is a testament to the urgent need for a tool that would make it possible to understand the contents better, notwithstanding even the fact that it had been "translated" into national languages".

The current Missale, however, refers to various other sources that constitute the heritage of the traditio that found its progressio in the Missale composed after the Second Vatican Council. It may be explained only through intimate knowledge of the sources, of which the Concordantia is a privileged instrument. We shall, therefore, present the Concordantia of the Gregorian, Veronese and Gelasian sacramentaries in that vein; they are the most important witnesses of that traditio, with their texts enjoying a significant presence in the current liturgical books?

\section{The concordances of the sacramentaries}

For over a millennium now, the euchological heritage of the liturgical books has been nourishing the faith of the Church. It is a rich intertwining of relationships, shown with concise clarity by Prosper of Aquitaine (d. after 455), who draws a tight connection between the lex orandi and the lex credendi $i^{8}$. The orations of the great sacramentaries ${ }^{9}$ and other

\footnotetext{
5 Missale Romanum ex decreto Sacrosancti Ecumenici Concilii Vaticani II instauratum, auctoritate Pauli PP. VI promulgatum, Ioannis Pauli PP. II cura recognitum, Editio typica tertia, Typis Vaticanis MMII, pp. 1318. The Decretum of approval bears the date of 20 April 2000! See the monographic file published in Rivista Liturgica 90/4 (2003) titled: Missale Romanum. La novitas della terza edizione latina. [T/N: Missale Romanum. The newness of the third Latin edition].

6 In the matter of the problems pertaining to the translations, see the monographic files published in Rivista Liturgica 85/6 (1998): Oltre la "traduzione”?; 92/1 (2005): Quale traduzione per una «liturgia autentica»?; 92/2 (2005): Tradurre testi liturgici: tra sfide e attese. A similar text is also found in Latinitas NS 2/1 (2014) 105-118, titled: Tradurre testi per la liturgia: difficoltà, sorprese, prospettive. - A separate volume contains the Concordantia by the Institutio Generalis Missalis Romani (Editio typica tertia): it is a work containing the Textus and the Concordantia (apart from other useful elements) in a way that gives an overview of the contents of the introductory part of the Missale: see M. Sodi-A. Toniolo (ed.), Prcenotanda Missalis Romani (Editio typica tertia). Textus - Concordantia - Appendices $=$ Monumenta Studia Instrumenta Liturgica 24, Libreria Editrice Vaticana, Vatican City, 2002, pp. XIV +807 .

7 For an overview of the current liturgical books, see the monographic file published in Rivista Liturgica $95 / 5$ (2008) titled: La liturgia di rito romano e $i$ suoi libri. - The three Concordantiae have been published in the "Veterum et Coaevorum Sapientia” [= VCS], edited by Editrice LAS: M. Sodi - G. Baroffio - A. Toniolo (ed.), Sacramentarium Gregorianum. Concordantia = VCS 7, Rome 2012; Sacramentarium Veronense. Concordantia $=$ VCS 10, Rome 2013; Sacramentarium Gelasianum. Concordantia = VCS 11, Rome 2014.

$8 \quad$ P. D’Aquitania, Indiculus de gratia Dei (cf. Denzinger-Schönmetzer 238-242: ... ut legem credendi lex statuat supplicandi). Further reading on the Trinitary faith and the consensus fidelium: see B. Studer, Lex orandi-lex credendi: Der Taufglaube im Gottesdienst der Alten Kirche, in E. Campi et Al. (ed.), Oratio. Das Gebet in patristischer und reformatorischer Sicht $=$ Forschungen zur Kirchen- und Dogmengeschichte 76, Vandenhoeck et Ruprecht, Göttingen 1999, pp. 139-149.

9 Starting several decades ago, the term "great sacramentaries" has been used to denote various important euchological traditions: see Appendix I.
} 
liturgical books reveal the prayerful elaborateness of theological thought ${ }^{10}$, encouraging further analysis and clarification ${ }^{11}$.

Only a few liturgical sources have been examined in a systematic manner with a final redaction of vocabulary indexes or complete concordance. For the most part, we are talking about works published in the appendices of certain editions, lexicographical research, and theological reflections upon single terms ${ }^{12}$ or more complex expressions ${ }^{13}$ : it is a rich body of material that would deserve being integrated with new studies, considering the indications of Appendix II of the present introduction.

A small portion of the euchological thesaurus generated over the centuries was included in the edition of the missal published by the Roman Curia (13th century), the direct predecessor of the Tridentine Missal ${ }^{14}$. The latter source of texts was a subject of concentrated attention of liturgists and philologists in the years surrounding the Second Vatican Council ${ }^{15}$. The advances in the field of digital technology have permitted the systematisation of data pertaining to the Latin-language missal ${ }^{16}$, and liturgical publications containing elements

10 For rudimentary orientation, see Glossarium medice et infimce latinitatis, conditum a Carolo Dufresne, domino Du Cange, auctum a monachis ordinis S. Benedicti cum supplementis integris D.P. Carpenterii et additamentis Adelungii, et aliorum digessit G.A.L. Henschel (...), Paris, Firmin Didot: 1 A-B 1840, 2 C-D 1842, 3 E-K 1844 , 4 L-O 1845, 5 P-R 1845, 6 S-Z 1846 (access: http://ducange.enc.sorbonne.fr; Thesaurus Linguae Latinae Editus auctoritate et consilio Academiarum quinque Germanicarum Berolinensis Gottingensis Lipsiensis Monacensis Vindobonensis, Lipsiæ, in ædibus Teubneri 1900-; A. Blaise, Le vocabulaire latin des principaux thèmes liturgiques. Ouvreage revu par A. Dumas, Brepols, Turnhout 1966; R.E. Latham et Al. (edd.), Dictionary of Medieval Latin Sources from British Sources, Oxford University Press for The British Academy, Oxford 1975-; A. Blaise, Dictionnaire latin-français des auteurs chretiens, revu specialement pour le vocabulaire théologique par H. Chirat, Brepols, Turnhout 1993.

11 It is fertile ground for research, notwithstanding the fact that at times researchers might arrive at starkly different conclusions. Think, for example, of the relationships between the prayers contained in the Ravenna scroll and the homiletic deliberations of the Bishop of Ravenna, Peter Chrysologus, which, surely enough, have been judged against by A. Olivar (Los sermones de San Pedro Crisologo. Estudio critico = Scripta et Documenta 13, Abadia de Montserrat 1962), and S. Benz (Der Rotulus von Ravenna nach seiner Herkunft und seiner Bedeutung für die Liturgiegeschichte kritish untersucht = Liturgiewissenschaftliche Quellen und Forschungen 45, Aschendorff, Münster 1967); A. Olivar's response, Abermals der Rotulus von Ravenna, in Archiv für Liturgiewissenschaft 11 (1969) 40-58.

12 In that respect, the bibliography is very broad; see Appendix II.

13 Take, for example, the work of G. Manz, Ausdrucksformen der lateinischen Liturgiesprache bis ins elfte Jahrhundert $=$ Texte und Arbeiten, 1. Abt., Beiheft 1, Erzabtei, Beuron 1941. It is a systematic research of the euchological material contained in the sacramentaries, aiming to identify the typical elements of every tradition and reveal the presence of foreignisms (e.g. hispanisms) in Roman sources; 1105 expressions have been taken into consideration, starting with abiectio carnis and ending with viventium omnium mater.

14 P. Bruylants, Les oraisons du Missel Romain. Texte et Histoire. I: Tabula synoptica fontium Missalis Romani. Indices. II: Orationum textus et usus juxta fontes = Etudes Liturgiques 1, Centre de Documentation et d'Information Liturgiques - Abbaye du Mont César, Louvain 1952. In volume I, the different euchological traditions, presented in single formularies, have been evidenced by approximately forty manuscripts and printed sources $(1474,1570$ and 1604 editions). Index verborum (incomplete): 217-281, Index orationum alphabetical: 283-330. A synoptic table showing the post-Pentecostal Sundays (16 sources): pp. 56-57. Volume II provides a textual critical apparatus for every prayer, sorted alphabetically. All of this material returns in the Liturgia tridentina volume, cit. note 1. Research such as that performed by Ellebracht, Remarks on the Vocabulary of the Ancient Orations in the Missale Romanum = Latinitas Christianorum Primæva 18, Dekker - van de Vegt, Nijmegen - Utrecht 1963, is very useful.

15 The work of A. Pflieger, Liturgica orationis concordantia verbalia, cit. above, note 2 . is innovative.

16 M. Sodi - A. Toniolo, Concordantia et indices Missalis Romani (Editio typica tertia) = Monumenta Studia Instrumenta Liturgica 23, Lev, Città del Vaticano 2002. The index may be accessed at http://www.rifugiodelleanime. org/m3. M. Sodi - A. Toniolo, Prcenotanda Missalis Romani. Textus - Concordantia - Appendices (Editio typica tertia) $=$ Monumenta Studia Instrumenta Liturgica 24, Lev, Città del Vaticano 2003. 
different from the traditional presidential orations ${ }^{17}$, such as for example hymns ${ }^{18}$. Owing to computer science, radical innovation in the composition of euchological concordances is being made. They are no longer limited to indicating single terms, but rather, as has already transpired in many biblical concordances, they place them in their respective contexts - and, it is worth remembering, the context often clarifies the meaning and functions of the term itself.

A relaunch of the liturgical literary heritage arrived with the edition of the reformed liturgy based on the direction assumed by the Second Vatican Council regarding both the Eucharist celebration and the Liturgy of the Hours. Important contributions are also made by the details hidden in modern-language translations as well ${ }^{19}$. The arrival of this springtime for research has been heralded by a renewed interest in Latin, and in the rich meanings of numerous expressions that, at the time, offered a broad palette of nuances in their meanings.

Thus makes itself palpable the possibility of making use of new lexicographical tools of work, capable of assisting the efforts of study in three fields:

- The knowledge of Christian spirituality and theological thought, materialising itself throughout the generations in the experience of local Churches, rallied to live a single, choral faith in shared enrichment, evidenced by the particular histories and sensibilities of every time and place. This field, first calling for the redaction, then fruition of concordances, is the most important and interesting one. From a tool of philological sciences, the concordances of orisons becomes one of mapping personal prayer among the unpredictable itineraries of the Spirit.

- Verbal concordances find their place among the most useful instruments of codicological research, offering itself to distinguish the respective traditions of the many books and smaller fragments spread in smaller portions everywhere; fragments that shed light on various difficulties associated with reading, starting with the poor condition many still find themselves in. This aspect is joined by the difficulty of distinguishing the nature of many acephalous pieces whose identification is scarcely or not at all aided by the most widespread alphabetical indices of the formulae.

- A field falling prey to the ebbs and flows of the current sad state of cultural affairs is that of Latin philology, Classical and Medieval alike. The fact that there still exist people willing and volunteering to occupy themselves with this branch, declared "dead" by many irresponsibles, is a strong reason for hope. Tools like concordances

\footnotetext{
17 For the episcopal blessings, see: E. Moeller, Corpus Benedictionum Pontificalium, I: Pars prima; II: Pars secunda; III: Concordantia verborum A-B; IV: Concordantia verborum $C-Z=$ Corpus Christianorum. Series Latina 162, 162A/C, Brepols, Turnholti, 1971 and 1979.

18 Cf G. Milanese, Concordantia et instrumenta lexicographica ad GRADUALE ROMANUM pertinentia, præfata est M. Ferrari = Bibliotheca Gregoriana 1, Editrice Liguria, Genoa - Savona 1996. Concordances of all of the words present in the Holy Mass hymns published both in Graduale Romanum (1974) and Antiphonale Missarum Sextuplex [n. 0902]. Among the lexicographical tools, it is necessary to indicate the retrograde alphabetical index: 395-431. The unpublished work of S. Jung Kim - Le Sequenze nei cinque Graduali della Biblioteca Capitolare di Benevento. Trascrizione diplomatica comparativa, apparato critico e musicale, analisi. Indice delle concordanze verbali $[\mathrm{T} / \mathrm{N}$ : The Sequences of the five Gradual Psalms of the Biblioteca Capitolare of Benevento. A comparative diplomatic transcription, critical and musical apparatus, and analysis. Index of verbal concordances] (doctoral thesis, typewritten) PIMS, Rome 1999 - presents a comparative edition of 130 pieces; the study and the apparatuses also takes into consideration evidence from Central Italy outside of Benevento. The alphabetical index of concordances is found in vol. IV, pp. 1104-1363.

19 See, for example, E. Mazza, Concordanze verbali delle collette e prefazi del messale romano italiano = Bibliotheca "Ephemerides Liturgicae". Subsidia 39, Clv, Rome, 1987, pp. 629.
} 
are, conversely, a stimulus for renewing interest in Latin philology; an opportunity to discover the twists and turns of the verbal labyrinths that the Latin language helps us navigate in order to reach the depths of the sense of what has been accomplished in the privileged space that the culmen et fons of Christian life remains to this day.

\section{The Tridentine sacramentary and the Gregorian tradition}

During the work on the project of composing a concordance of the Gregorian sacramentary, one of the foremost questions was that of selecting the base texts. Among the possibilities were certain modern editions: from the revision of Cambrai $164^{20}$ through that of Autun $19 \mathrm{bis}^{21}$ to that of Paduense D $47^{22}$. At the conclusion of various evaluations, by no means diminishing the value of the other texts, the Trentine sacramentary was chosen ${ }^{23}$.

The codex written in Trent, or in a part of Alto Adige close to it, today remains preserved in one of the surrounding localities ${ }^{24}$. The Tridentine sacramentary is a sound piece of evidence of the Gregorian euchological tradition present in Italy that preceded the book sent by Pope Hadrian to the Frankish court. Moreover, notwithstanding certain additions of the era that

20 J. Deshusses (ed.), Le sacramentaire Grégorien. Ses principales formes d'après les plus anciens manuscrits. Edition comparative. I: Le sacramentaire. Le supplément d'Aniane = Spicilegium Friburgense 16, Ed. Universitaires, Fribourg 1971. An edition containing an apparatus of parallel sources (including Veronese and Gelasian) and a critical apparatus based on the Autun Missal, Bibl. Municipale, 19 (Marmoutier, ca. 845); Cambrai, Bibl. Municipale, 162 and 163 (Abbey of Saint-Vaast s. IX2); Donaueschingen, Hofbibl., 191 (Constance s. IX 3/4); Düsseldorf, Landes-u. Stadtbibl., D1 (Essen s. IX 1/4); Firenze, Bibl. Med. Laurenziana, Edili 121 (Northern Italy. s. IX ex-X in); Köln, Bibl. des Metropolitankapitels, 88 (Cologne [ed. Pamelio] sec. IX ex-X in); 137 (Cologne s. IX 2); Le Mans, Bibl. Municipale, 77 (Saint-Amand s. IX 3/4); London, British Library, Add. 16605 (Stavelot s. IX 2); Mainz, Seminarbibl., 1 (St. Alban of Mainz s. IX ex); Modena, Bibl. Capitolare, O.II.7 (Modena or Reggio Emilia s. IX $m$ ); Monza, Bibl. Capitolare, Sacramentario di Berengario, Northern France s. IX m); New York, Pierpont Morgan Libr., G 57 (Saint-Amand, later Chelles, ca. 860); Oxford, Bodleian Libr., Auct. D.I.20 (San Gallo s. IX 2); Add. A 173 (France? s. IX m); Padua, Bibl. Capitolare, D 47 (France, Northern Italy s. IX 2/4 m); Paris, BNF, lat. 2290 (Saint-Amand s. IX 2); lat. 2292 (court of Charles the Bald s. IX 3/4); lat. 2812 (Lyon s. IX 1); lat. 9429 (Northern France s. IX 2); lat. 12050 (Corbie 853); Sainte-Geneviève, 111 (Paris s. IX 2); Reims, Bibl. Municipale, 213 (Saint-Amand 870 c.); Rome, BAV, Oct. lat. 313 (Paris Cathedral s. IX 3/4); Regin. lat. 337 (Lione s. IX 1); Trent, Bibl. Provinciale d'Arte, 1590 (Trent s. IX 1); Verona, Bibl. Capitolare, XCI (Verona s. IX 1/4); LXXXVI (Verona s. IX 2/3); Wien, Österreichische Nationalbibl., lat. 1815 (Reichenau s. IX m); Zürich, Zentralbibl., Rheinau 43 (Northern France s. IX ex).

21 J. Décréaux, Le sacramentaire de Marmoutier (Autun 19 bis) dans l'histoire des sacramentaires carolingiens du IXe siècle. I: Etude. Revue et mis au point par V. Saxer; II: Texte. Revue et mis au point par V. Saxer = Studi di antichità cristiana 38, Pontifical Institute of Christian Archaeology, Vatican City, 1985.

22 A. Catella - F. Dell'Oro - A. Martini (edd.), in collaboration w/F. Crivello, Liber Sacramentorum Paduensis (Padova, Biblioteca Capitolare, cod. D 47) = Monumenta Italiæ Liturgica 3, Edizioni Liturgiche, Rome 2005, pp. 595.

${ }^{23}$ For various hypotheses pertaining to the nature, dating, and origin of the sacramentary, see the exhaustive study by F. Dell'Oro in Monumenta Liturgica Ecclesice Tridentince sceculo XIII antiquiora. II A: Fontes liturgici. Libri sacramentorum. Studia et editionem paravit F. Dell'Oro, adlaborantibus B. Baroffio - I. Ferrari - H. Rogger, Società di Studi Trentini di Scienze Storiche, Trent 1985, pp. 18-47. A handful of other texts clarify certain details, e.g.: J. Deshusses, Le sacramentaire grégorien de Trente, in Revue Bénédictine 78 (1968) 261-282; K. Gamber, Der Codex Tridentinus (Ein Sakramentar der Domkirche von Säben aus der Zeit um 825), in Scriptorium 24 (1970) 293304 + pl. 17; F. Unterkircher, Das karolingische Sakramentar von Trient für Säben geschrieben?, in Der Schlern 51/1 (1977) 54-60 + $10 \mathrm{Abb}$.

24 Presently found in Trent, Biblioteca vescovile del Castello del Buonconsiglio, Cod. 217. From 1803, the manuscript was found in Vienna, Kaiserliche und Königliche Hofbibliothek (currently the Österreichische Nationalbibliothek), Cod. Vindobonensis 700; in 1919, the book was returned to Trent and is presently preserved in the Castello del Buonconsiglio, Monumenti e Collezioni provinciali, 1590. 
followed, the Tridentine sacramentary seems to represent the most archaic of the revisions of the Gregorian sacramentary ${ }^{25}$.

\subsection{Observations pertaining to the text of the concordances}

The base text used to compose the concordances is that of the 1985 edition $^{26}$, used as a reference for every orthographical peculiarity of the manuscript. This edition made changes in more places, correcting errors and/or graphical anomalies that have been partly pointed out in the apparatus ${ }^{27}$.

In light of the concordance, it has been deemed opportune to make amendments to the text in order to render the alphabetical series of the terms considered optimal. For example, the "e" present in diphthongs (ae/oe) has thus been in every case rendered as "ae". Given the presence of different lections of the exact same term, all of the variants have been traced back to the correct or most commonly found lections ${ }^{28}$. Thus, the variants that are found in the second part have been, apart from certain proper nouns, harmonised with those found in the first ${ }^{29}$.

\subsection{The Concordantia}

The Concordance of the Tridentine sacramentary examines the texts of the formulae without further specific indications pertaining to their use.

The one-line KWIC procedure was chosen, as the Sacramentaries contain a very high number of short formulae. The occurrences of the terms have been presented following the numerical progression of the Sacramentary's formulae; thus, the use of the terms is captured in the context of singular sections of the Sacramentary, allowing for more accurate study. This type of concordance is called KWIC (key word in context), as the words subject to research are aligned with and surrounded by context on both sides. In this case, the selected alignment is "centred".

Every liturgical formula, no matter its length, has been considered a separate area of research. The " $/$ " symbol present in certain lines indicates the separation of a given formula from the one that follows it; thus, the reader is pointed either to the beginning or the end of the formula.

\footnotetext{
25 Cf Deshusses, Le sacramentaire Grégorien. Ses principales formes, pp. 71-72.

26 Monumenta Liturgica Ecclesice Tridentince. II A: Fontes liturgici, pp. 73-416. The text was established by Dell'Oro; Baroffio collaborated on the apparata. These concordances only pertain to the euchological texts of the sacramentary, not the two lists of the Capitula and the few lecture and hymn texts inserted in a certain few formularies.

27 For example, in formula no. 22, the manuscript features the form pleps, corrected in the text as plebs; formula no. 44 features tua (moderamine), amended as tuo. For further reading on the graphical peculiarities related to the grammatical order and phonetics, see: Dell'Oro, Fontes liturgici, pp. 66-67.

28 Of particular note is the case of the term missa, sometimes assumed with absolute value, used to convey various [instances of] ad missa. That notwithstanding, it was always read as ad missam; on the other hand, the Incipiunt missas part was rendered with missae.

29 Judging by the nomenclature, as well, sometimes veering towards preference of terms typical of the Gelasian tradition, one can clearly see that the second part of the sacramentary has a history different from that of the first. secreta e post communionem invece di super oblata e ad complendum. For the sake of uniformity, certain terms found in the original text have been modified; the lections have been pointed out in the apparatus.
} 
It was necessary to remove all of the phonetic accents from the vowels, and diphthongs (æ, $œ)$ have been conveyed using two letters each; the ques have not been removed. The letters $\mathrm{J}, \mathrm{K}$, and W have not been removed; however, a single instance of the letter $\ddot{\boldsymbol{e}}$ is present in the word aëris.

When it came to the correct alphabetical order, all of the letters have been considered to be lower-case, even if the definitive transcription written with an upper-case letter appears as in the text.

Lines have been made to contain 70 characters each; their initial and final words, divided due to this choice, have been automatically eliminated. Thus, certain lines are longer, and certain ones are shorter.

The total number of occurrences precedes the term itself, marked in bold type. The searched term is found in the middle of the line and marked in bold; even if more than one instance appears, it is only counted once.

5966 terms have been examined, with a grand total of 36979 words.

It is possible to browse the various terms in order to see the number of a particular occurrence; various terms, even though always signalled, have not been taken into consideration given their lack of relevance for the aim of studying euchology. Finally, the Appendix lists the terms according to the number of occurrences, from et, appearing 1633 times, to the many instances of unicum.

\section{The Veronese Sacramentary}

October 1713 saw a discovery of exceptional interest for liturgical sciences and the cultural traditions of the West. The marquis of Verona, Scipione Maffei (1675-1755), found a codex that had laid hidden away for centuries, along with other important ancient manuscripts; the significance of this unicum was immediately understood.

The longing to understand this text would produce four editions in the very same 18th century alone, and then a fifth one in the 19th and a later sixth one, which remains the base of the current concordance ${ }^{30}$. The critical edition by Mohlberg contains a detailed description of the manuscript, its linguistic characteristics (orthography, inaccuracies, grammar, clauses), contents, and characteristics, attempts at dating the Veronese Sacramentary (Mohlberg lists at least 85), the relationship between this sacramentary and the other Latin-language sacramentaries, a description of the first editions, and the fundamentals of the edition itself, published in 1954.

Exactly three centuries afterwards appeared our Concordantia. The fortuitous coincidence was also accompanied by the 50th anniversary of the Sacrosanctum Concilium in a joyful encounter that permitted what the very same Concilium affirmed in Article 23 in regard to

\footnotetext{
30 The first edition was created, according to Maffei, who denominates it "Veronese", by Oratorian Giuseppe Bianchini: Codex sacramentorum vetus Romanae Ecclesiae a sancto Leone papa I confectus [...], in Francsco Bianchini, Anastasii Bibliothecarii de vitis Romanorum Pontificum, vol. IV, Rome 1735; the text is a precise one also owing to the improvements made. The second edition was created by Ludovico Antonio Muratori: Liturgia romana vetus, vol. I, Venice, 1748; the next edition was that by Giuseppe Luigi Assemani: Codex liturgicus ecclesiae universae, vol. 6, Rome, 1748; the work was curated by brothers Pietro e Gerolamo Ballerini: S. Leoni Magni opera omnia, vol. II, Venice, 1756; finally, there is the edition by Charles Lett Feltoe: Sacramentarium leonianum, Cambridge 1896.
} 
the close relationship between tradition and progress in liturgical reform, to be carried out once more through "accurate theological, historical and pastoral investigation".

\subsection{The Sacramentarium}

Attributed to Pope Leo the Great $(\dagger 461)$, the euchological collection conserved in the Biblioteca Capitolare di Verona (manuscript LXXXV [80]), has been referred to as the "Leonine Sacramentary" for a number of centuries; for a few decades now, however, preference was given to the more neutral denomination of the "Veronese Sacramentary". The detailed codicological, historical, and liturgical studies permitted a more adequate evaluation of the book, containing over 1300 ancient liturgical orisons meant for eucharistic celebration $^{31}$. More than a sacramentary in the strictest meaning of the word, it is a collection of libelli missarum, the most ancient one of its kind, precious for the understanding of the Urban liturgy, the theological thought, and the Latin language in its liturgical rendition.

Based on the edition of the Sacramentarium Leonianum curated by Feltoe ${ }^{32}$, which, from a critical standpoint, is superior to those of the 18th century, Placide Bruylants published a monumental verbal concordance of the Veronese sacramentary immediately after the war ${ }^{33}$. The modern edition, curated by L.C. Mohlberg ${ }^{34}$, has established a more critical text with a meticulously-prepared philological apparatus to aid the interpretation of the less clear passages; guesswork and operations aiming to reconstruct a reliable version of the text are certainly not amiss ${ }^{35}$.

In the view of the editing of our concordance, it was necessary to uniformise the different spellings found in the codex ${ }^{36}$ and normalise the text in accordance with the modern spelling of the Latin language ${ }^{37}$. The edition includes corrections and guesswork of the Mohlberg edition $^{38}$, while all of the original terms found in the Veronese manuscript can be found at $w w w$.liturgia.it. Normalising the text was necessary to allow for the use of the concordance without too many obstacles. For example: whoever wishes to study the ecclesiological aspects

\footnotetext{
31 A substantial, updated bibliography, as yet unpublished, has been edited by Monsignor Andrzej Suski, Bishop of Toruń, Poland. The repertory contains numerous studies pertaining to theological themes and single terms.

32 Charles Lett Feltoe, Sacramentarium Leonianum Edited, with Introduction, Notes and Three Photographs, Cambridge, Cambridge University Press 1896. The volume is accessible at http://archive.org/details/sacramentariuml00feltgoog

33 Placide Bruylants, Concordance verbale du Sacramentaire Léonien [ms. Vérone, Bibliothèque Capitulaire, LXXXV (80)], Louvain, Editions de l'Abbaye du Mont César s. d., pp. XVI + 697. This pertains to an excerpt from “Archivum Latinitatis Medii Aevi” (Bulletin Du Cange) 18, 1945, 51-376 and 19, 1948, 39-405.

34 Sacramentarium Veronense (Cod. Bibl. Capit. Veron. LXXXV [80]). In Verbindung mit Leo Eizenhöfer OSB und Petrus Siffrin OSB herausgegeben von Leo Cunibert Mohlberg OSB, Rome, Herder 1954 (Rerum Ecclesiasticarum Documenta. Series maior. Fontes 1). Third edition, revised and updated by Leo Eizenhöfer in 1966, anastatic reprint, 1994.

35 Apart from the notes contained in the critical apparatus, see especially section $\S 2$ of the introduction, pp. XLLIII "Die spraclichen Eigentümlichkeiten des Textes", examining the orthography, errors, and grammar. Finally, various studies have been brought up in the cursus of the text.

36 To give a few examples: "adiuvari" - "adiubari", "adiuvetur" - "adiubetur", "evangelistae" - "evangeliste", "obtineat" - "optineat", "plebem" - "plevem", "votiva" - "votiba"; "affectum" - "adfectum"; "praesta" - "presta"; "implere" - "inplere"...

37 Cfr. the terms found in the dictionary by Georges-Calonghi.

38 The editors' additions have been added in italics.
} 
found in the Veronese Sacramentary would not find anything if the search term ecclesia was used, as the sacramentary consistently uses the spelling of aeclesia/ae/am.

Written in Verona in the first half of the 7th century, the Veronese Sacramentary contains the fullest and most ancient organic collection of Roman euchology. As evidenced by the numerous amendments and additions to the original text as well ${ }^{39}$, the status of the document is uncertain. The "unenthusiastic" ${ }^{" 40}$ and oftentimes corrupted ${ }^{41}$ conveyance of the orisons does not, however, diminish the importance of the preserved texts, which reflect an archaic state of the liturgical life of the Church and Rome. Suffice it to think of the alternative lections of the texts ${ }^{42}$, a likely echo of the peculiar relationship between the liturgical texts before they were strictly established in writing. Particular attention is piqued by the many texts that seem to circumscribe this piece of evidence in light of their absence from the widespread and confirmed Gelasian and Gregorian traditions ${ }^{43}$.

The complexity of the textual conveyance of the Veronese Sacramentary emerges from the terms' original spelling found in the manuscript, as presented in two lists accessible at $w w w$. liturgia.it. One of the lists contains cases with peculiar spellings ${ }^{44}$, while the other gathers the cases of corrupted or flawed spelling ${ }^{45}$.

\footnotetext{
39 The edition by Mohlberg indicates all of the amendments made to the text, almost always by way of erasing and substituting letters and/or words. When possible, the apparatus also provides the original lections. For example, in the case of "intuere" (orison no. 10), it is signalled that the " $u$ " was written over a previously-erased letter, possibly an " $e$ ". In the initial word of oration no. 23 "Sumentes", the second " $e$ " replaces the original " $i$ ". - Among the interventions, one should make note of the numerous single letters and full words written between the lines and in the margins. In this edition of the normalised text, such additions are indicated in boldface. One example of this is the word corda of orison 127. Using the apparatus, one may deduce that it is a first-hand correction in the external margin, meant to substitute the term peccata expunged from the text, evidenced by the "Vatican" Gelasian Sacramentary of 1103. - Later additions are present as well, such as the one inserted by an Italian at the end of the 8th century after the final line of f. 24v (which would fall between orison 253 and the preface 254): Preces populi tui, quaesumus, domine, clementer adsume, ut nos servos tuos custodias ab omni malo adque defendas.

40 Such a lack of enthusiasm was noted after the editing of the code already and has resulted in corrections. In many cases, the amendments still permit the recognition of the erased or substituted letters, all of which were minutely signalled in the Mohlberg edition. In many cases, however, only the substitution is legible.

${ }^{41}$ An example from among the many cases indicated in the apparatus pertains to preface no. 244. The verb consecrari is either changed to consecrasti or integrated with dignatus es. In some cases, it is the comparison between parallel passages of the Veronese Sacramentary or other euchological sources that allows us to trace the correct lection of the text. In preface no. 124, for example, the beginning of Quorum martyrum is rendered as Quoniam martyrum owing to the current revision of the same book (no. 410) and other Gelasian, Gregorian, and Ambrosian sacramentaries.

42 Following the Mohlberg edition, the alternative lections are indicated as follows: $|: \mathrm{xxx}:|$. In cases not indicated in that edition, but signalled as guesswork in the apparatus, such lections are indicated thus: (:| xxx |:).

43 In recent years, evidence of texts reputed exclusive to the Veronese Sacramentary has been distinguished in peripheral euchological sources in Piacenza and Split (Croatia) for some isolated cases.

44 The first list contains the terms in the alphabetical order: ac (= hac) 197 954, acerva 20, acervum 1216, Adauti 800801 , Adcumula 988, adcumulet $9241217 \ldots$

45 The second one lists the terms in accordance with the progression of the orisons. The first column offers the amended text of the Mohlberg edition, while the second contains the original lections, followed by the numbers of their respective orations.
}

innumerae in munere 11

confessione confessione( $m$ espunto) 15

sustinere sustinuere 20

quoque quosque 22 


\subsection{The base text of the sacramentary}

The text upon which the later concordance was based is that by Mohlberg. Intense revisory work on the Latin text has been conducted in order to provide a linguistically-correct, easily-usable version.

In line with this, apart from what was already raised, additions between the lines and on the margins have been evidenced in bold, while those of the Mohlberg edition have been indicated in italics.

The original abbreviations of the codex have been removed, much like the doxologies of the orisons and prefaces. For a complete verification, it is always right and proper to refer to the critical edition.

\subsection{The Concordantia and the Appendices}

In order to formulate the concordance of the Sacramentarium Veronense, made up of 139 pages $[(20 \times 8$ sheets $=160$ pages +1 single +1 double $=163-24(3 \times 8$ sheets $)=139]$, starting with the euchological material for 14 April, from among the various editions, we have chosen the critical edition as the base for reformulation: Sacramentarium Veronense, curated by LEO CUNIBERT MOHLBERG OSB, Casa editrice Herder, Rome, 1956 (Series maior, Fontes I, RED)

1331 euchological pieces + two marked as bis, making a total of 1333 orisons and prefaces, grouped in formularies, made up of more euchological pieces.

If one were to speak of formularies alone, the count would stand at 134 with 685 euchological pieces, difficult to find in the yearly schedule, which provides a backing capacity.

Among the formularies, there are both complete and incomplete ones, with the frequent presence ITEM ALIA, which could indicate a continuous process of accumulation.

The choice has been made to maintain these texts as they are presented in their textual entirety, even if repetitive or very similar to one another: the formulae are not many, and are often brief.

As with the preceding concordance of the Gregorian Sacramentary of Trent ${ }^{46}$, the texts of the formulae have been taken into consideration without any further specific indications that could accompany them.

Every liturgical formula, no matter its length, has been considered a separate area of research. The "/" symbol present in certain lines indicates the separation of a given formula from the one that follows it; thus, the reader is pointed either to the beginning or the end of the formula itself.

In the text of the concordance, the total number of a term's occurrences precedes the term itself, marked in boldface.

The occurrences of the terms have been presented following the numerical progression of the Sacramentary's formulae; thus, the use of the terms is captured in the context of singular sections of the Sacramentary, allowing for more accurate study.

The searched term is found in the middle of the line and marked in bold; even if more than one instance appears, it is only counted once.

46 Sacramentarium Gregorianum. Concordantia, a cura di Manlio Sodi - Giacomo Baroffio - Alessandro Toniolo, Libreria Ateneo Salesiano, Rome, 2012. 
Lines have been made to contain 70 characters each; their initial and final words, divided due to this choice, have been automatically truncated. Thus, certain lines are longer, and certain ones are shorter.

When it came to the correct alphabetical order, all of the letters have been considered to be lower-case, even if the definitive transcription written with an upper-case letter appears as in the text.

The analysis of this sacramentary employs the simplest form of concordance, KWIC, as well, as the examined words are aligned and surrounded on both sides by context. In this case, the chosen alignment is "centred".

5966 terms have been examined, with a grand total of 36979 words. Finally, the terms have been shown according to the order in which they appear; for the alphabetical order, please refer to the website indicated above. The most common terms are ut (893 instances) and et (1552).

Browsing the Concordance, the reader will find that, in the case of many terms, only the number of occurrences is given. In order to avoid making the volume too unwieldy, we have deemed it opportune to retain all of the terms useful for the aim of philological and theological research.

We also deemed it a good idea to contain the alphabetical list of the incipit of all of the prefacial embolisms. Finally, in the second part, one may find the occurrences of the terms according to the order of their appearance.

\section{4. "Reginensis 317 "}

Among the many merits that Queen Christina of Sweden (Stockholm 1626 - Rome 1689) accumulated over her lifetime, researchers of the Christian cult emphasise a single one: having acquired, among others, the Sacramentarium Gelasianum codex, brought it to Rome after her conversion to Catholicism (1654), and, above all, having brought it to the Apostolic Library of the Vatican. All of this was the fruit of her passion for ancient books and manuscripts, and her longing to make Stockholm the Athens of the North!

It is due to this fact that the codex containing the sacramentary and numerous other texts was named reginensis upon its reception by the Library of the Vatican ${ }^{47}$ after having been acquired by Pope Alexander VIII following the Queen's death in 1689, along with the rest of her library. In the mean time, Cardinal Giuseppe M. Tomasi had the opportunity to publish a printed edition in $1680^{48}$.

47 Cf A. Wilmart, Codices Reginenses latini, vol. II, Apostolic Library of the Vatican, Vatican City, 1945.

48 Cf Codices Sacramentorum nongentis annis vetustiores... primum prodeunt cura et studio Ioseph Mariae Thomasij... Romae MDCLXXX. The Italian translation of the text of the Praefatio has been published in Rivista Liturgica 101/3 (2014) 461-476. At the beginning of this work, Tomasi formulates the following dedication: "Quos Codices abhinc complura saecula conscriptos Munificentia Tua mihi concessit edendos: hos nunc fui foecundus exemplis Maiestati Tuae iure restituo. Qua in re utrumque gratulor, et sine prisci characteris molestia in hoc uno volumine eos lectitare Te posse: et de Re Sacra optime meritam ex eisdem apud eruditos omnes haberi. Accipe ergo quod praeclaram decet Sapientiam, Religionemque tuam: atque in eo summae observantiae in Te meae obsequium humaniter admitte. Vale». - For an adequate presentation of the figure and the work, see: I. Scicolone, Il cardinale Giuseppe Tomasi di Lampedusa e gli inizi della scienza liturgica = Cultura cristiana di Sicilia 6, Palermo, 1981; G.L. Masetti Zannini, Giuseppe Maria Tomasi, Cardinale santo e liturgista principe, Curia Generalizia dei Padri Teatini, Rome 1986; F. Andreu, Pellegrino alle sorgenti. S. Giuseppe Maria Tomasi. La vita - Il pensiero - Le opere, Curia Generalizia dei Chierici Regolari (Teatini), Rome, 1987. 
The "Gelasian" authorship may, according to the majority of scholars, be traced to Valafrido Strabone († 849), who "attributed" it to Pope Gelasius (an African; reigned 492496), perhaps in order to grant more authority to the contents, which were composed later than his pontificate, even though, granted, one may agree that part of the libelli came from Gelasius, seeing as a note in Vita Gelasii of Liber Pontificalis affirms: «... fecit etiam et Sacramentorum praefationes et orationes cauto sermone...» ${ }^{49}$; not subjecting the work of G. Pommarès to discussion ${ }^{50}$.

Posing the question of the work's "fatherhood", the work was compiled in the 8th century in Paris (the monastery of Chelles?) with the inclusion of Gaulish, and, above all, Roman elements (in the opinion of J. Morin and many other scholars after him), but the contents date as far back as the 6th century. Due to this, it has been denominated Sacramentarium Gelasianum Vetus in order to distinguish it from its remakes of the same name that may be dated back to the 8th century, the product of combining the Gelasian Sacramentary with a Paduan version of the Gregorian one. The Gregorian Sacramentary is complete with all of the celebrations of the liturgical year, sacraments, and various occasions; all of the contents are featured and articulated in three tomes. It is of fundamental importance for the numerous texts that pertain to initiation to Christianity, the liturgical year, and other sacraments, but also for the abundance of formularies meant for various occasions.

\subsection{The Sacramentarium Gelasianum Vetus}

The "Gelasian" nucleus is, in chronological terms, the second of the three principal euchological constellations of the Roman Catholic Church. The most antique Veronese "sacramentary" and the more recent Gregorian collection are strictly connected to Rome, while the Gelasian one offers a take on the Roman tradition integrated with trans-Alpine material, a fact explained by the manuscript's French origins.

In the other areas of Medieval Latin Europe, important traditions have existed, evidenced by but a few isolated pieces of evidence such as, for example, the Missale Gothicum, which sheds light on the complex reality of the Frankish world ${ }^{51}$.

In order to distinguish the peculiarities of a single component of the liturgical heritage, especially euchological, it does not suffice to merely scrutinise the analysis of the scarce sources that have survived until our times. On the contrary, the "scandalous" slightness of evidence entices one to conduct studies entailing heortological comparison, as well as comparison of texts between their sources and various environments. Sometimes, the results of this research - which, by now, has accumulated over a century's worth of painstaking and productive activity - have proven surprising, such as when Edmund Bishop discovered the famous Spanish Symptoms in areas far removed from the Iberian Peninsula, even in the immediate Roman area itself ${ }^{52}$.

\footnotetext{
49 L. Duchesne, Liber Pontificalis, vol. I, 1955, p. 255.

50 Cf. G. Pommarès (ed.), Gélase Ier: Lettre contre les lupercales et dix-huit messes du sacramentaire Léonien= Sources Chrétiennes 65, Cerf, Paris 1959.

51 Cf L.C. Mohlberg (ed.), Missale Gothicum (Vat. Reg. lat. 317) = Rerum Ecclesiasticarum Documenta, Series Maior, Fontes V, Herder, Rome, 1961.

52 Cf E. Bishop, Spanish Symptoms, in Liturgica Historica. Papers on the Liturgy and Religious Life of the Western Church, Clarendon Press, Oxford 1918, pp. 165-202 (publ. 1907).
} 
This work, encompassing numerous disciplines - from the paleography of texts to that of music, from the history of Church institutions to that of liturgy, from the cult of the Saints to classical- and middle-Latin philology, from literature to theology and iconography - is still not close at all to having reached its objective, i.e. an adequate understanding of the ecclesiastical world, that has crystallised in the texts of the sacramentaries and other liturgical books.

\subsubsection{The present-day accessibility of an abundance of documentation}

In current times, this long, demanding march has been facilitated by numerous critical editions of liturgical texts, as well as countless essays and articles. A particular contribution is made by repertories of philological-and-theological character. Georg Manz provided a model to follow when pursuing research in various directions ${ }^{53}$. Then there are the repertories focused on single sources, producing ever-useful concordances of words ${ }^{54}$. An imminent publication certain to raise the interest of many researchers is the "Guide to the Manuscripts" of pre-Tridentine missals and sacramentaries of Italian origin ${ }^{55}$.

This work fills a large gap and makes accessible the complete list of words that emerge from the euchological texts of the vetus Gelasian Sacramentary ${ }^{56}$.

53 Cf G. Manz, Ausdrucksformen der lateinischen Liturgiesprache bis ins elfte Jahrhundert = Texte und Arbeiten 1. Abt. Beiheft 1, Erzabtei, Beuron 1941. It is systematic research of the euchological material of the sacramentaries, meant to distinguish the typical elements of every tradition and reveal the presence of foreign (e.g. Spanish) expressions in Roman sources. 1105 expressions, from abiectio carnis to viventium omnium mater.

54 Cf. C. Mohlberg - L. Eizenhöfer - P. Siffrin (ed.), Sacramentarium Veronense (Cod. Bibl. Capit. Veron. LXXXV [80]) $=$ Rerum Ecclesiasticarum Documenta, Series Maior, Fontes 1, Herder, Rome2, 1966. Apart from the 1331 formulae of the Veronese Sacramentary, the Scroll of Ravenna has been published: pp. 174-178 and p. 203, Fragments Milan, Bibl. Ambrosiana, O 210 sup., f. 46 (6th-7th centuries): pp. 178-180; Fragments Stuttgart, Württ. Landesbibl., H.B. VII 10 (7th-8th centuries): pp. 180-181; The particular orations of the Gelasian Sacramentary "Phillipps", Berlin, Staatsbibl., Phillipps 1667: pp. 182-199; the Mone Fragment, Karlsruhe, Badische Landesbibl., Aug. CCLIII, f. 96v: pp. 200-201; the Anonymous Arian Fragments, Vatican City, BAV, Vat. lat. 5750, f. 73-74: pp. 201-202. Indices of the quotes and biblical recollections: pp. 230-234; terms: pp. 235-438. - For the Ambrosian area, see also: O. Heiming, Das Sacramentarium Triplex. Die Handschrift C 43 der Zentralbibliothek Zürich. I: Text; J. Frei, Das Sacramentarium Triplex. Die Handschrift C 43 der Zentralbibliothek Zürich. II: Wortschatz und Ausdrucksformen. Ein Wortverzeichnis = Liturgiewissenschftliche Quellen und Forschungen $49=$ Corpus Ambrosiano-Liturgicum 1, Aschendorff, Münster W. 1968 and 1983. - For the texts of the hymns of the Proprium Missae see: G. Milanese, Concordantia et instrumenta lexicographica ad Graduale Romanum pertinentia, praefata est M. Ferrari = Bibliotheca Gregoriana 1, Editrice Liguria, Genua-Savona 1996. This pertains to the Concordances of all of the words present in the Mass hymns, published both in the Graduale Romanum of 1974 and in the AMS [R.-J. Hesbert, Antiphonale Missarum Sextuplex d'après le graduel de Monza et les antiphonaires de Rheinau, du Mont-Blandin, de Compiègne, de Corbie et de Senlis, Vromant \& C, Bruxelles 1935]. Among the lexicographical instruments to be indicated in the Concordantia is the retrograde alphabetical index: pp. 395-431.

55 A work of G. Baroffio - M. Sodi-A. Suski, Sacramentari e messali pretridentini di provenienza italiana. Guida ai manoscritti, Società Bibliografica Toscana, Torrita (Siena) 2015 (being published).

56 Cf L.C. Mohlberg - L. Eizenhöfer - P. Siffrin (ed.), Liber Sacramentorum Romanae Aeclesiae ordinis anni circuli (Cod. Vat. Reg. lat. 316/Paris Bibl. Nat. 7193, 41/56) (Sacramentarium Gelasianum) = Rerum Ecclesiasticarum Documenta, Series Maior, Fontes 4, Herder, Rome3, 1981. The manuscript contains 1704 formulae. Furthermore, the volume contains the Exorcismus contra energumenos (nn. 1705-1725), the Iudicium paenitentiale (nn. 1726-1786), the Breviarium Apostolorum... (nn. 1787-1799) originating from the Bibliotheque nationale de France; apart from these, fragments of "Bannister", Paris, BnF, lat. 10837, 42v-43r (Echternach sec. VIII/2, pp. 265-266) and "Baumstark", London, British Libr., Add. 37518, pp. 116-117 (England? Northern France? 8th century, pp. 266-267). - For the bibliography, see the ample review published in the reprint in 1981, pp. 325-330, in addition to what has been brought up in note 13 . 


\subsubsection{The witness of particular traditions}

The codex remains virtually the only complete piece of evidence of a particular eucological tradition that, as signalled, blends the Frankish and Roman ones ${ }^{57}$.

Many centres have been thought to be the central nucleus of the sacramentary. A hypothesis, as of now refuted, was proposed by Klaus Gamber, a tireless researcher of liturgical sources, whose interpretation was aided by a visionary fantasy. He is credited with ascribing the Gelasian Sacramentary to Ravenna ${ }^{58}$.

Presently, it is universally agreed that the book is Roman, but the opinions pertaining to the details diverge. Almost everywhere, the long, but not always solid narrative by Antoine Chavasse, published in 1957, is used as a point of reference ${ }^{59}$. With time, everyone started repeating his simple hypotheses as if they were indisputable facts.

In that situation, accepting new scenarios that would cause a certain sort of intellectual panic is difficult; too many cosy houses of cards, providing shelter and comfort, would crumble. Thus, the shrewd and firm essay of Massimo Martelli has been and remains almost completely ignored ${ }^{60}$.

\subsubsection{From the Gelasian sacramentaries of the 8th century to the Gregorian tradition}

The numerous satellites encircling the complex Gelasian agglomerate around the Vetus - the eighth-century Gelasian sacramentaries and those of the last generation ("Young") composed

57 Certain data of a philological nature emerge from the lists and apparatuses found in works such as P. Bruylants, Les oraisons du Missel Romain. Texte et Histoire. I: Tabulae synopticae fontium Missalis Romani. Indices. II: Orationum textus et usus juxta fontes = Etudes Liturgiques 1, Centre de Documentation et d'Information Liturgiques - Abbaye du Mont César, Louvain, 1952. Volume I presents - in single formularies - the various euchological traditions evidenced by approximately forty manuscripts and printed works. Index verborum (incomplete): pp. 217-281, Index orationum, alphabetical: pp. 283-330. The work has been reproduced in M. Sodi - A. Toniolo - P. Bruylants (edd.), Liturgia Tridentina. Fontes - Indices - Concordantia 1568-1962= Monumenta Liturgica Piana 5, Libreria Editrice Vaticana, Vatican City, 2010. More works: J. Deshusses - B. Darragon, Concordance et tableaux pour l'étude des grands sacramentaires, I: Concordance des pièces; II: Tableaux synoptique; III: Concordance verbale $A$-D; IV: Concordance verbale E-L; V: Concordance verbale M-P; VI: Concordance verbale $Q-Z=$ Spicilegii Friburgensis Subsidia 9-14, Ed. Universitaires, Fribourg 1982 [I-III] and 1983 [IV-VI]. All of the orisons present in the "great sacramentaries": Veronese (Leonine), Gelasian, Hardianic Gregorian, the supplement by Anianus, 8th century Gelasian (Gellone, Angoulême, San Gallo 348) have been processed. Vol. I contains the alphabetical index of all of the orisons, vol. II presents a prospect of all of the formularies and single formulae (4258) according to their succession in every source, while volumes III-VI contain the verbal concordances of all of the words present in all of the formulae. - B. Coppieters't Wallant, Corpus Orationum, incomplete version by E. Moeller, subsequently I.M. Clément, 14 voll. = Corpus Christianorum, Series Latina 160 A-M, 161, Brepols, Turnholti 1992-2004. In the first 9 volumes, they have been listed in the alphabetical order and with a variant apparatus of all of the Mass orisons published in modern editions.

58 Cf K. Gamber, Codices Liturgici Latini Antiquiores = Spicilegii Friburgensis Subsidia 1, Universitätsverlag, Freiburg 21968, pp. 299-318; for information on the Gelasian sacramentaries of the 8th century, see. pp. 368-397.

59 Cf A. Chavasse, Le sacramentaire Gélasien (Vaticanus Reginensis 316). Sacramentaire presbytéral en usage dans les titres romains au VIIe siècle $=$ Bibliothèque de théologie IV: Histoire de la théologie 1 , Declée \& Cie, Parigi... 1958.

60 For the hypothesis on super sindonem in the Roman liturgy, see: A.M. Martelli, Un fenomeno della liturgia gallicana e del Gelasiano: le messe con più orazioni prima della segreta, in Studia Patavina 19 (1972) 539-579= A.M. Martelli, Contributi allo studio del Sacramentario Gelasiano Reg. 316 (Nuove prospettive per la spiegazione della sua formazione). An extract from the thesis presented at the Theological Faculty of the Pontifical Atheneum of St. Anselm in Rome, Padua 1973; A.M. Martelli, Un fenomeno della liturgia gallicana e del gelasiano: le messe con più orazioni prima della segreta, in Studia Patavina 20 (1973) 546-569; A.M. Martelli, Il Sacramentario gelasiano. Cod. Vat. Reginense 316. Primo testimone completo dell'esperimento della Liturgia Romana nella Gallia Precarolingia, Vita Trentina Editrice, Trent, 2003. 
before the integration with the Gregorian tradition and the formulation of the mixed books - constitutes a relevant problem.

These sacramentaries are compilations brought about by "une réorganisation, effectuée à partir d'organisation antérieures" 61 . The exact problem is that of pinpointing the sources and editing works. Also in this case, the philological analyses carried out by Bernard Moreton have resonated neither with adequate strength nor the mental flexibility indispensable for opening oneself to unexpected, if by no means new, philological perspectives ${ }^{62}$.

Suffice it to say that the "version found in the Gelasian, directly drawn from by the Gelasian Sacramentaries of the 8th centuries, precedes, in certain cases, the very same version found in the Veronese, or at least in several smaller versions of this classical collection". Furthermore, Moreton proposes that the version found in the Gelasian Sacramentaries may have been composed "in a Benedictine centre of the zone close to the Rhaetian Alps, towards the third quarter of the eighth century. From there, the Sacramentary would quickly spread to various regions" ${ }^{\prime \prime}$.

These few mentions allow a glimpse on the importance of tools such as the discussed concordance. Certainly, when it comes to the history of the (Roman) euchological traditions, it is necessary to study and confront the evidence in its entirety - the complex articulation of the sections and formularies, the rendition of the single orisons and particular texts (not to forget the indices).

In order to distinguish the various layers of the liturgical books - layers that emerge from the semantic modifications and use of particular terms typical of certain linguistic and cultural areas, as well as from certain points in time - it is urgent and necessary to resume the comparative analyses on the lexicographical level as well.

\subsection{The base text of the sacramentary}

The text constituting the base of the present work is the one by Mohlberg, already adduced. Its critical edition offers a starting point not for redoing what has already been done, but, rather for offering the Latin text in the most correct version possible. It is the only way to proceed towards creating a concordance capable of maintaining dialogue with other sources, both first-millennium and, above all, modern.

${ }^{61}$ A. Chavasse, Le sacramentaire dans le group dit «Gélasiens du VIIIe siècle». Une compilation raisonnée. Etudes des procédés de confection et Synoptique nouveau modèle, I: Etudes particulières; II: Synoptiques et tableaux speciaux $=$ Instrumenta patristica 14 A/B, Abbatia S. Petri - M. Nijhoff, Steenbrvgis - Hagae 1984; a quote from vol. I, p. iii. Cf. M. Klöckener, Sakramentarstudien zwischen Fortschrift und Sackgasse. Entschlüsselung und Würdigung des zusammenfassenden Werkes von Antoine Chavasse über die Gelasiana des 8. Jahrhunderts, in Archiv für Liturgiewissenschaft 32 (1990) 207-230.

${ }_{2}$ Cf. B. Moreton, The Eighth-Century Gelasian Sacramentary. A Study in Tradition = Oxford Theological Monographs, Oxford University Press, Oxford 1976. An important case preceding the Gelasian collections - which occurred to Giacomo Baroffio when, in 1976-1977, he first read the essay by Moreton - is that of the literary tradition of Pater noster conveyed by the Gospels of Matthew and Lucas. According to Joachin Jeremias, the version most elaborate when it comes to the length of the text, has introduced new formulae; when it came to its vocabulary and use, however, it reflects the original.

63 Citazione dalla recensione di G. Baroffio (B.B.) in Rivista Liturgica 66/5 (1979) 714-716: 715; scheda 21 del Bollettino bibliografico. 
As is the case with the Gregorian and Veronese Sacramentaries ${ }^{64}$, the most difficult and demanding task is that of giving a linguistically-correct form of all of the Gelasian Sacramentary's own formulae.

The formulae present in the critical edition of Mohlberg's work at the end of the sacramentary itself have not been taken into consideration, as the edition stops at formula no. 1704 , concluding with explicit.

Critical re-reading of the entirety of the text allowed for uniformisation of certain spellings and, in some cases, interpreting certain expressions. This is the perspective on correct Latin that becomes accessible with philological study of the terms confronting both the previous two sacramentaries and the Missale Romanum, both in its form composed in the wake the Council of Trent and that following the Second Council of the Vatican ${ }^{65}$.

Studying the Gelasian Sacramentary in detail, as with the aforementioned Gregorian and Veronese, offers an opportunity not merely to grasp the richness of the texts, but, above all, the abundance of theological and liturgical perspectives that may only be revealed by diligent "meditation" upon the text. When later - quod faxit Deus! - one may taste the wealth of the three most ancient sacramentaries of the Western tradition in live language as well, the work on the Concordantiae will strike as much less arid than it may indeed seem.

Between the many surprises that an attentive scholar may discover, there is also text no. 312 , containing the traditio Symboli with interlinear transliteration of Greek. This document seems to be the most ancient one evidencing the transliteration of the Greek text of the times when this language was no longer used for celebration in Rome ${ }^{66}$.

Thus, the base text allows us to approach this sacramentary according to the original order of the formulae as well; it also permits a more thorough reading the text reproduced at the order of Paul VI in $1975^{67}$ : a work which crowns, in the words of E. Burque, «... un des plus précieux documents liturgiques que la Providence nous ait conservé. C'est grâce à lui... qu'on est enfin arrivé à voir un peu clair dans l'histoire liturgique prégrégorienne et à résoudre des problèmes... qui autrement seraient demeurés d'éternelles énigmes... $\rangle^{68}$.

\subsection{The Concordantia and the Appendices online}

As previously stated, in order to compose the concordance of the Sacramentary, we have chosen the critical version curated by L.C Mohlberg - L. Eizenhöfer - P. Siffrin. Il Cod. Vat.

\footnotetext{
${ }^{64}$ See the previous two concordances, edited by M. Sodi - G. Baroffio - A. Toniolo, Sacramentarium Gregorianum. Concordantia $=$ Veterum et Coaevorum Sapientia $[=$ VCS $]$ 7, Libreria Ateneo Salesiano, Rome, 2012; Sacramentarium Veronense. Concordantia $=$ VCS 10, Libreria Ateneo Salesiano, Rome, 2013.

65 In this regard, see the two concordances edited by M. Sodi - A. Toniolo, Liturgia Tridentina ... cited in note 10, as well as the Concordantia et Indices Missalis Romani. Editio typica tertia = Monumenta Studia Instrumenta Liturgica 23, Libreria Editrice Vaticana, Vatican City, 2002.

${ }^{66}$ The Concordantia does not consider the transliterated Greek terms, as this would be superfluous work.

67 Cf Sacramentarium Gelasianum e Codice Vaticano Reginensi Latino 316 vertente anno sacro MCMLXXV iussu Pauli PP. VI phototypice editum = Codices e Vaticanis selecti..., vol. XXXVIII, In Civitate Vaticana MCMLXXV. The volume accompanying the edition contains two studies: L. Michelini Tocci, Il manoscritto [history, writing, ornamentation, description], pp. 3-26; B. Neunheuser, Il «Sacramentario Gelasiano» (Reg. lat. 316) e la sua importanza per la storia della liturgia, pp. 27-46. The text by Michelini Tocci has been picked up and published in Rivista Liturgica 101/3 (2014) 477-500.

68 E. Bourque, Étude sur les sacramentaires romains. Première partie: Les textes primitifs = Studies of Christian Antiquity 20, Pontifical Institute of Christian Archeology, Rome, 1948, p. 187.
} 
Reg. Lat. 316, totalling 245 progressively-numbered pages starting at the 3rd and ending at the 245th (no. 1-1704) as the point of reference. The final part of the codex, not included in the publication, corresponds to ff. 41-56 of Latin codex no.7193 (no. 1705-1799).

The 1704 euchological pieces, organised in the formularies according to a well-defined plan and divided into the books, contain "timed" (no. 1-803), "sanctoral" (804-1177), and "non-timed" (no. 1178-1704) texts.

The Gelasian Sacramentary is a book that has been specifically prepared for ministerial intervention and indicates both the actions to be undertaken by the ministers and the words that are to accompany the liturgical gesturality. The passages contained therein are, therefore, present in the form of fully-transcribed texts which, on the one hand, describe the behaviour of the ministers, and, on the other, recall their very own words.

In the process of "modelling" for the edition of the concordance, all of the terms pertaining to the gestures have been eliminated, indicated in the published text by underlining (and correspond to the "indices"). Thus, the titles of the formularies have not been taken into consideration.

The euchological texts of the formulae have been entirely conserved as they were, and, as is the case with the previous concordances of the Trentine, Gregorian and Veronese Sacramentaries, the further specific indications have been removed.

Repeating what was written in the previous editions of the concordances, every liturgical formula, no matter the length, has been considered an area of research of its own. The "/" symbol present in various lines is a separation mark between the formulae, thus showing the reader where one ends and another begins.

In the text of the concordance, the total number of a term's occurrences precedes the term itself, marked in boldface. The occurrences are presented according to the numerical progression of the formulae in the Sacramentary; thus, one may grasp the use of the term within the single sections, allowing for more careful study.

The search terms are indicated within the lines in boldface, and, even if they appear more than one time, are counted only once.

Given that the number of formulae contained in the Gelasian Sacramentary is greater than that found in the preceding two, the lines have been set to contain 65 characters each for the sake of making the physical copy lighter; the initial and final words broken up due to this have been automatically removed. Thus, certain lines are longer, and certain ones are shorter.

When it came to the correct alphabetical order, all of the letters have been considered to be lower-case, even if the definitive transcription written with an upper-case letter appears as in the text.

In the case of this sacramentary, the simplest form of concordance, KWIC, has been employed as well, as the words subjected to research are aligned with and surrounded by context on both sides. In this case, the chosen alignment is "centred".

Browsing the Concordance, the reader will find that, for many terms, only the number of occurrences has been given; in order to avoid making the volume too heavy, we deemed it prudent to conserve the terms that are useful for philological and theological text. The remaining terms (let us keep in mind that every choice is always subject to debate!) are accessible at www.liturgia.it. 


\section{Conclusion: Per philologiam ad theologiam}

The only aim of the trilogy of concordances is that of facilitating familiarisation with the three most ancient sacramentaries, much of whose richness would find its way into the Missale Romanae Curiae ${ }^{69}$, the Missale Romanum composed in the wake of what was established by the Council of Trent ${ }^{70}$, and, above all, the Missale Romanum (and other liturgical works as well), whose re-working was desired by the fathers of the Second Council of the Vatican ${ }^{71}$.

Such a trilogy may provoke various levels of appreciation. The scholar, however, knows that the main objective of it all is that of philological study aiming to grasp the theological richness of terms typical of euchology. A richness that may only be scrutinised when one gives value to philology and syntagmatic analysis as a tool for evidencing - in dialogue with all of the parallel expressions - the theological peculiarities of a given term as part of the formula it is found in, even more so of the formulary itself and the liturgical times it is mean to be thought, written and invoked in.

It is the liturgical - and, in a broader sense, theological and "sacramental" - methodology that benefits from similar instruments of work. The history of strictly liturgical hermeneutics has recently made significant advances; a kind of hermeneutics that touches upon all of the languages of the Christian cult, and especially pertaining to euchological texts.

The intertwining of biblical and liturgical hermeneutics has revived a more direct focus on the relationship between the Bible and liturgy ${ }^{72}$, causing the re-emergence of a "page" that was well-known during the times of the Fathers, and is today hailed, like never before, as a guarantee of further in-depth analysis in light of theology and liturgical spirituality born of the experience of the Christian cult and traced back to it by way of philological and textual study as well ${ }^{73}$.

There are many possible reasons to deepen the knowledge of the Missale Romanum. When, however, one wishes to delve into the substance of the meanings of single terms, the syntagms to which they belong, and the formulae in which they appear... resorting to such an instrument of comparison is indispensable in order to verify the various semantic roles that a given term may assume within the same formula, formulary, liturgical period, et cetera ${ }^{74}$. Only a philological and semantic examination allows for the understanding of the contents of the choice of a given term over another.

\footnotetext{
69 Cf. R. Lippe (ed.), Missale Romanum. Mediolani 1474, I.: Texte = Henry Bradshaw Society 17, London, 1907.

70 Cf. M. Sodi - A.M. Triacca (ed.), Missale Romanum. Editio princeps (1570) = Monumenta Liturgica Concilii Tridentini 2, Libreria Editrice Vaticana, Vatican City2, 2012.

71 For the Missale Romanum of the Second Vatican Council and a complete overview of the liturgical books, see: Rivista Liturgica 90/4 (2003) Missale Romanum. La «novitas» della terza edizione latina; 95/5 (2008) La liturgia di rito romano e i suoi libri; 97/3 (2010) La tradizione liturgica della Chiesa di Roma; amd 98/3 (2011) Ermeneutica del libro liturgico.

72 In this regard, see the precious contribution of A.M. Triacca, Bibbia e liturgia, in D. Sartore - A.M. Triacca C. Cibien (edd.), Dizionario di liturgia, San Paolo, Cinisello B. (Mi) 2001, s.v.

73 Two recent examples may be found in Latinitas NS: M. Sodi, Latinitas liturgica. Una pagina esemplare circa il rapporto tra Scrittura ed eucologia, 1, 2013, 51-72; F.M. Arocena, Analecta hymnica Ecclesiae: himnarios e himnos, 2, 2014, 69-82.

74 See, for example, the type of analysis of euchological texts possible to be conducted in view of distinguishing the contents, in the elaborate study by M. Sodi, La "latinitas" dei libri liturgici. L'eucologia del "Tempus Adventus" nel "Missale Romanum" di Paolo VI: dalla filologia alla teologia eucaristica, in E. dal Covolo - M. Sodi (edd.), Il latino e i cristiani. Un bilancio all'inizio del terzo millennio = Monumenta Studia Instrumenta Liturgica 17, Libreria Editrice Vaticana, Vatican City, 2002, pp. 375-488 (its ample bibliography included).
} 
The currency of the Concordantia stems from the fact that it allows for the appreciation of this abundant heritage, whose richness renders it difficult to make use of; the confrontation of the contents of, for example, the current edition of the Missale with those of the Tridentine; the in-depth examination of the choices in the selection of the texts (both those not made, but, rather, opportune, and others that result as redundant or deceptive in light of tradition); the achievement of their translation into living languages, verifying the use of a given term in varied contexts.

In other words, only a tool of this kind allows the unity to be grasped, and the biblical, theological and liturgical richness present in the texts composed to celebrate the Eucharist and other sacramentaries in accordance with the Roman rite, to be appreciated. And this is a wish we make to whoever consults these pages.

In this light, even the aridity of a given concordance may offer a precious contribution to understanding the ever-newer aspects of the theological richness that emanates from the celebration of the sacred mysteries, and, by extension, the richness of the Word of God that the authors of the formulae had an inclination of offering us in everlasting, for always current, texts $^{75}$.

\section{The Concordantia of the three great sacramentaries: Gregorian, Veronese and Gelasian \\ Summary}

The "tradition" of the Church never ceases to amaze us with its wealth and the characteristics of its documents. The liturgical tradition contributes to this in an important way as well. Finding the appropriate tools to learn about these documents is of great importance. In this way, the great work done by the three scholars of liturgy is a beacon and an appeal. Looking through all of the texts reveals the infinity of elements which, without any shadow doubt, can be a great help per philolgiam ad theologia or ad culturam!

Keywords: Concordantia, Sacramentary, Church

About the Author: Don prof. Manlio Sodi is a professor emeritus of the Università Pontificia Salesiana; his scientific patrimony encompasses works in the fields of history and liturgics. For over twenty years, he was an editor of the Liturgica review.

About the Author: prof. Giacomo Baroffio is a professor emeritus of musicology at the University of Pavia; presently, he is researching the history of musical texts from the first millennium.

About the Author: dott. Alessandro Toniolo is currently researching liturgical source texts.

75 Cf. M. Sodi - M. Maritano (edd.), Leone I e Gregorio I. Attualità di due "grandi” promotori di cultura. Presentazione di E. Prinzivalli = Vivae Voces 29, Lateran University Press, Vatican City, 2015. 